\title{
Impediments countenanced by Lucknow Chikankari artisans
}

\author{
RITU AGRAHARI AND KANWALJIT KAUR BRAR
}

Received: 06.03.2017; Revised: 18.09.2017; Accepted: 04.10.2017

See end of the paper for authors' affiliations

\section{RITU AGRAHARI}

Department of Apparel and Textile Science, Punjab Agricultural University, LUDHIANA (PUNJAB) INDIA

Email : rituagrahari088@

gmail.com
DABSTRACT : The Indian handicraft sector forms a major part of the rich cultural heritage of the country. Lucknow has carved out a name for itself in the field of chikankari craft. The number of chikankari artisans in Lucknow runs in thousands, yet the sector remains unorganised with no medical insurance, social and financial security. The chikankari artisans, especially those working for private enterprises, faced many difficulties regarding lack of skill up-gradation and direct marketing of the products. So, the prime objective of the study was to investigate the problems countenanced by chikankari artisans. A self-structured interview schedule was administered to a sample of 300 artisans who were randomly selected from the five blocks of the Lucknow district. Low wages as per intricacy and skill of work (66.00\%), irregular payment $(54.66 \%)$ were the major financial issues of the artisans, besides facing work related health problems like backache (36.33\%), cervical spondylosis (4.66\%) and eye strain (41.00\%). No artisans got the medical benifits from any of the organizations/enterprises. They were vulnerable to exploitation due to poor marketing intelligence (29.00\%), and irregular orders (10.67\%). Inadequate transportation facility (39.32\%), poor road infrastructure ( $81.00 \%)$, and poor electric supply $(78.00 \%)$ led to wastage of time and low productivity. For the upliftment of artisans, government needs to develop more clusters, organise trainings and workshops for skill development and enhancing marketing. There is utmost need to address to these problems.

- KEY WORDS: Embroidery, Chikankari, Artisans, Problems experienced

- HOW TO CITE THIS PAPER : Agrahari, Ritu and Brar, Kanwaljit Kaur (2017). Impediments countenanced by Lucknow Chikankari artisans. Asian J. Home Sci., 12 (2) : 339-348, DOI: 10.15740/HAS/AJHS/12.2/ 339-348. 